\title{
Bacterial enteritis of cultured flounder Paralichthys olivaceus larvae
}

\author{
K. Muroga ${ }^{1}$, H. Yasunobu ${ }^{1}$, N. Okada ${ }^{1}$, K. Masumura ${ }^{2}$ \\ ${ }^{1}$ Faculty of Applied Biological Science, Hiroshima University, Higashi-Hiroshima 724, Japan \\ ${ }^{2}$ Hiroshima Prefectural Fisheries Experiment Station, Ondo 737-12, Japan
}

\begin{abstract}
Chokan-hakudaku-sho' is a devastating disease of larval Japanese flounder Paralichthys olivaceus caused by a bacterium tentatively named Vibrio sp. INFL after the disease it causes: intestinal necrosis of flounder larvae. The disease was reproduced in 16 to 27 -d-old flounder larvae by oral challenge with Vibrio sp. INFL was incorporated into brine shrimp Artemia salina nauplii or rotifers Brachionus plicatilis, but not in older fish. Histopathological and electron microscopic examinations revealed that pathogen multiplication and resultant pathological changes occurred only in the intestine. Although pili-like structures were not observed on the cells of the pathogen, an adhesive property was demonstrated on a chinook salmon embryo (CHSE-214) cell line.
\end{abstract}

\section{INTRODUCTION}

National and prefectural agencies in Japan are actively engaged in the hatchery propagation of various marine fishes to augment declining populations in coastal waters (Fukuhara 1987). The Japanese flounder Paralichthys olivaceus is one of the most important species propagated, with an estimated 20 million juveniles produced in 1987. Production techniques for this species are well established; however, difficulties sometimes are encountered in controlling diseases which can cause mass mortalities in larval and juvenile stages.

A disease called 'Chokan-hakudaku-sho' in Japanese, which means a disease condition characterized by an opaque intestine, has been known to occur in larval flounder. The cause was thought to be a vibrio isolated from affected intestines (Murata 1987). We subsequently characterized the pathogen in detail and tentatively named it Vibrio spp. INFL after the disease it causes: intestinal necrosis of flounder larvae (Masumura et al. 1989). This disease was reproduced in larval flounder by oral administration of the pathogen incorporated into live food organisms, the rotifer Brachionus plicatilis and brine shrimp Artemia salina nauplii. In the present paper, we describe the age-dependent lethality and the pathogenesis of this bacterial enteritis using infection experiments and histopathological examinations.

\section{MATERIALS AND METHODS}

Infection experiments. Six groups of flounder of varying age $(11,16,17,27,41$ and 60 d old $)$ were orally challenged with a virulent strain (FH-8804) of Vibrio sp. INFL. Brine shrimp nauplii were suspended for 30 min in sand-filtered seawater $\left(25^{\circ} \mathrm{C}\right)$ containing $1 \mathrm{mg}$ wet weight [ca $10^{9}$ colony forming units (CFU), cultured on ZoBell's $2216 \mathrm{e}$ agar at $25^{\circ} \mathrm{C}$ for $24 \mathrm{~h}$ ] of $\mathrm{FH}$ 8804 per $\mathrm{ml}$. The Vibrio sp. cells, thus incorporated into nauplii, were given to test flounder for 3 consecutive days at a ratio of $1 \mathrm{~g}$ wet weight of food per fish group, consisting of 10 (60-d-old), 25 (41-d-old) or 50 (other age groups) individuals per $20 \mathrm{l}$ tank. For a group of 11 $\mathrm{d}$-old fish, bacteria-loaded rotifers were given instead of infected brine shrimp nauplii because the fish were too small to eat nauplii. From the 4th day, the test groups received non-treated live diets, which were also used to feed the respective control groups. Fish were kept at about $20^{\circ} \mathrm{C}$ for $6 \mathrm{~d}$ from the first oral challenge, and during this period dead fish were removed and the water was partly replaced with fresh seawater daily. Dead fish (except decaying ones) were cultured for the presence of bacteria.

An injection challenge was conducted in a separate experiment. Because of the fragility of younger larvae during handling, only a group of 41-d-old $115.6 \mathrm{~mm}$ average total length) juveniles were injected intraperitoneally with Strain FH-8804. For reference, a 
Vibrio anguillarum isolate Strain PT-81049, isolated from a diseased ayu Plecoglossus altivelis, was also injected into flounder juveniles of the same age. The injected dose of FH-8804 and PT-81049 was $4.4 \times 10^{8}$ and $3.6 \times 10^{8} \mathrm{CFU}$ fish $^{-1}$, respectively, and the fish were kept at about $20^{\circ} \mathrm{C}$ for $1 \mathrm{wk}$.

Histopathological examinations. A group of larval flounder (20-d-old, $10.6 \mathrm{~mm}$ average total length) held at $20^{\circ} \mathrm{C}$ was given rotifers containing $\mathrm{F}-2$, another virulent strain of Vibrio sp. INFL (Masumura et al. 1989), for 3 consecutive days. After the first administration of the pathogen, 3 to 4 fish were collected at intervals of $\mathrm{ca} 12 \mathrm{~h}$ for $5 \mathrm{~d}$. Fish samples, including control fish which were fed non-treated rotifers, were fixed in Bouin's solution, embedded in paraffin, sectioned at 5 m, and stained with haematoxylin and eosin or methylene blue.

For examinations with scanning electron microscope (SEM) and transmission electron microscope (TEM), larvae with opaque intestines in orally challenged groups ( 3 to $4 \mathrm{~d}$ after the first challenge) and noninfected fish in control groups were sampled. For SEM examination, intestines were fixed in $1 \%$ cacodylate buffered glutaraldehyde and postfixed in $1 \%$ osmium tetroxide in the same buffer. The samples were sputtercoated with a thin layer of gold and examined with a SEM (JEOL, JSM-T20). For TEM examination, a specimen of the intestine was fixed in a $2.5 \%$ glutaraldehyde $-2 \%$ paraformaldehyde mixture in phosphate buffer ( $\mathrm{pH} 7.4$ ) and postfixed in $1 \%$ osmium tetroxide in the same buffer. Thin sections were stained with $1 \%$ uranyl acetate and $1 \%$ lead citrate and examined with a TEM (Hitachi HU-11DS) at $75 \mathrm{kV}$ accelerating voltage.

Adherence of Vibrio sp. INFL to CHSE-214 cells. CHSE(chinook salmon embryo)-214 cells cultured at $20^{\circ} \mathrm{C}$ for $2 \mathrm{~d}$ in Eagle's minimum essential medium supplemented with $10 \%$ fetal bovine serum were used for an adherence test. Bacterial cultures of 4 strains of Vibrio sp. INFL (F-2, FH-8804, F-1a, F-2a) grown on brain heart infusion agar containing $3 \% \mathrm{NaCl}$ were suspended in Hank's balanced salt solution (HBSS) at about $10^{8} \mathrm{CFU} \mathrm{ml^{-1 }}$. The virulence of Vibrio $\mathrm{sp}$. INFL strains was apt to be lost on repeated subcultures, and Strains F-1a and F-2a were attenuated strains derived in this manner from virulent $F-1$ and $F-2$ strains, respectively. Strain FH-8804 was used in place of Strain F-1 because virulent F-1 strain was no longer available when this experiment was conducted. The presence or lack of virulence in all of these strains was confirmed by oral challenge in larval flounder. Each bacterial suspension was applied to CHSE-214 cell cultures and agitated gently at $20^{\circ} \mathrm{C}$ for $1 \mathrm{~h}$. Then, the cell cultures were washed with HBSS 4 times, fixed with methanol, and stained with May-Grünwald and
Giemsa solutions. Incidence of adherence (percentage of CHSE-214 cells with adherent bacteria) and intensity of adherence (average number of bacteria adhering to one cell) were determined for each strain by observing 1000 cells.

\section{RESULTS}

\section{Susceptibility of flounder}

In the group of 11 -d-old fish (youngest group), $14 \%$ of the test fish died but this mortality was similar to that of the control (Table 1), and opaque intestines were not

Table 1. Paralichthys olivaceus. Susceptibility of flounder of different ages to oral challenge with Vibrio sp. INFL (FH-8804)

\begin{tabular}{|c|c|c|c|}
\hline $\begin{array}{l}\text { Fish age } \\
\text { (d post- } \\
\text { hatching) }\end{array}$ & $\begin{array}{l}\text { Average } \\
\text { total } \\
\text { length } \\
(\mathrm{mm})\end{array}$ & $\begin{array}{l}\text { Challenge } \\
\text { dose } \\
\left(\mathrm{CFU}^{\mathrm{b}} \mathrm{g}^{-1}\right. \\
\text { food })\end{array}$ & $\begin{array}{l}\% \text { Mortality } \\
\text { (dead/tested) } \\
\text { in } 6 \mathrm{~d}^{\mathrm{c}}\end{array}$ \\
\hline 11 & 6.5 & $\begin{array}{c}1.0 \times 10^{8} \\
0\end{array}$ & $\begin{array}{l}14.0(6 / 43) \\
16.7(8 / 48)\end{array}$ \\
\hline 16 & 8.2 & $\begin{array}{c}4.1 \times 10^{8} \\
0\end{array}$ & $\begin{array}{r}36.0(18 / 50)^{d} \\
2.0(1 / 50)\end{array}$ \\
\hline 17 & 10.2 & $\begin{array}{c}1.1 \times 10^{9} \\
0\end{array}$ & $\begin{array}{l}74.5(38 / 51)^{d} \\
18.0(9 / 50)\end{array}$ \\
\hline 27 & 11.3 & $\begin{array}{c}1.1 \times 10^{9} \\
0\end{array}$ & $\begin{array}{l}56.0(28 / 50)^{d} \\
16.0(8 / 50)\end{array}$ \\
\hline 41 & 15.6 & $\begin{array}{c}1.1 \times 10^{9} \\
0\end{array}$ & $\begin{array}{ll}0 & (0 / 25) \\
0 & (0 / 25)\end{array}$ \\
\hline 60 & 37.1 & $\begin{array}{c}1.1 \times 10^{9} \\
0\end{array}$ & $\begin{array}{ll}0 & (0 / 10) \\
0 & (0 / 10\}\end{array}$ \\
\hline \multicolumn{4}{|c|}{$\begin{array}{l}{ }^{a} \text { Cell concentration of FH- } 8804 \text { strain in rotifers (for } 11-\mathrm{d} \\
\text { old fish) or brine shrimp nauplii. (for other age groups, } \\
\text { which were administered for the first } 3 \mathrm{~d} \\
{ }^{b} \text { Colony forming units } \\
{ }^{c} \text { Water temperature }=19.0 \text { to } 20.7^{\circ} \mathrm{C} \\
{ }^{d} \text { Different significantly }(\mathrm{p}<0.01 \text { ) from each correspond- } \\
\text { ing control (Osaki 1979) }\end{array}$} \\
\hline
\end{tabular}

observed in any fish. In the groups of 16, 17, and 27-dold fish, the mortality of the test groups was significantly higher than that of the respective controls. The characteristic clinical sign of the disease, an opaque intestine (Fig. 1), occurred and subsequently Vibrio sp. INFL was isolated from the intestines in these 3 test groups. In older fish groups $(41,60$-d-old), no apparent changes were observed in the test groups or in the controls

In the injection challenge, only $8^{\circ}(2 / 25)$ of the fish injected with Vibrio sp. INFL (FH-8804) died, while all 

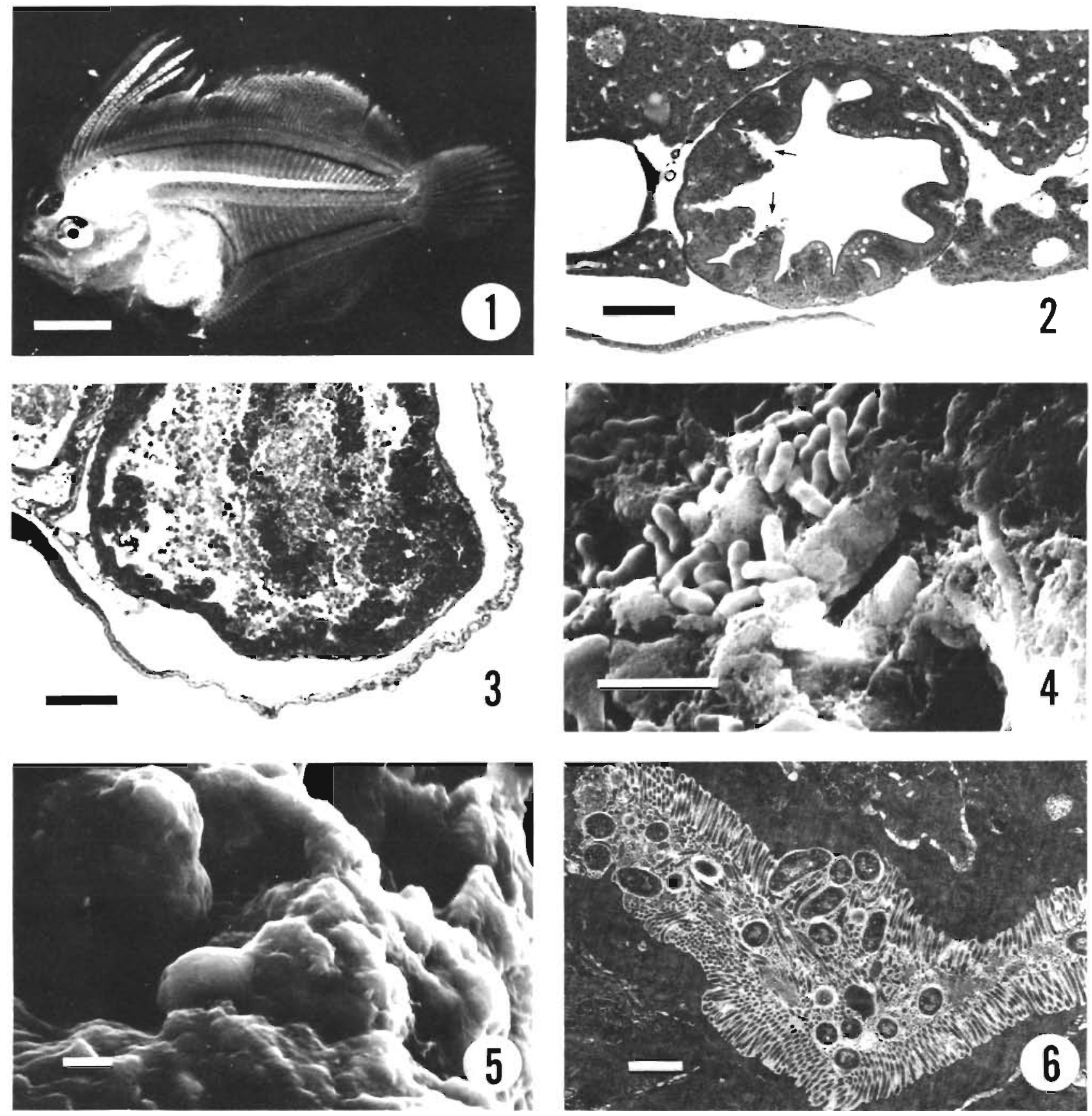

Fig. 1 to 6. Paralichthys olivaceus. Fig. 1. A diseased flounder larva showing the opaque intestine typical of Vibrio sp. INFL enteritis. Fig. 2. Section of intestine from infected fish $(80 \mathrm{~h}$ after oral challenge) showing necrosis and focal erosion of the epithelial layer of the intestine (arrows). Fig. 3. Section of infected fish (105 h) showing intestine filled with necrotic epithelial cells and cellular debris. Fig. 4. Cells of Vibrio sp. INFL on the mucosal surface of the intestine. Fig. 5. Mucosal surface of the intestine of a non-infected fish. Fig. 6. Cells of Vibrio sp. INFL between microvilli of the intestine. Scale bars $=2 \mathrm{~mm}$ (Fig. 1), $100 \mu \mathrm{m}$ (Figs. 2 and 3), $5 \mu \mathrm{m}$ (Figs. 4 and 5), and 1 m (Fig. 6) 
of the fish injected with $V$. anguillarum (PT-81049) died. No fish showed intestinal opaqueness in either group.

\section{Histopathology}

No lesions were observed in the intestine or other organs of orally challenged fish until $44 \mathrm{~h}$ after the first administration of bacteria-loaded rotifers. At this time, vacuolation of the epithelial cells and mild focal erosion of the mucosal surface were observed in the posterior intestine. After 70 to $80 \mathrm{~h}$, focal necrosis and sloughing of the intestinal mucosa occurred (Fig. 2). At this time, a slight degeneration of hepatic cells and renal tubular epithelium was observed. After $105 \mathrm{~h}$, the intestinal tract was filled with detached epithelial cells and cellular debris (Fig. 3), and the degeneration involved the submucosa and muscularis. Specimens stained with methylene-blue revealed the presence of bacterial colonies along the affected intestinal wall but not in the spleen, liver or kidney.

SEM examination showed that many bacterial cells, identical in appearance, were attached to the inner mucosal surface of the posterior intestine (Fig. 4). Bacteria isolated from different individuals of a given group were shown by the slide agglutination test using an antiserum against Vibrio sp. INFL (Masumura et al. 1989) - to be identical to the administered pathogen. In contrast, no bacteria were observed on the mucosal surface of the intestine from non-infected fish (Fig. 5). A TEM photograph (Fig. 6) indicates that the bacterial cells were present between the microvilli and that some were attached directly to the surface of epithelial cells. However, pili-like structures were not observed even at a high magnification

\section{Adherence to CHSE-214}

The prevalence and intensity of adherence to CHSE214 cells were greater in virulent strains than in avirulent strains (Table 2).

\section{DISCUSSION}

We reported in an earlier paper (Masumura et al. 1989) that 'Chokan-hakudaku-sho' was reproduced in larval flounder by oral challenge with Vibrio sp. INFL incorporated into rotifers or brine shrimp nauplii, but not by immersion challenge. In the present study, an intraperitoneal injection with the pathogen also failed to produce the disease in juvenile flounder. In contrast, $V$. anguillarum, a pathogen known to cause systemic infections, killed juvenile flounder following intra-
Table 2. Vibrio sp. INFL. Comparison in adherence to CHSE214 cells of virulent and avirulent strans of Vibrio sp. INFL

\begin{tabular}{|c|c|c|c|}
\hline Strain & $\begin{array}{c}\text { Inoculum } \\
\left(\mathrm{CFU}^{\mathrm{a}} \times 10^{7}\right. \\
\left.\mathrm{ml}^{-1}\right)\end{array}$ & $\begin{array}{l}\text { Incidence of } \\
\text { adherence } \\
\qquad(\%)^{\mathrm{b}}\end{array}$ & $\begin{array}{c}\text { Intensity of } \\
\text { adherence } \\
\text { (bacteria/cell) }\end{array}$ \\
\hline \multicolumn{4}{|l|}{ Virulent } \\
\hline FH-8804 & 6.4 & 86.5 & 7.7 \\
\hline F-2 & 5.0 & 93.7 & 9.9 \\
\hline \multicolumn{4}{|l|}{ Avirulent } \\
\hline F-1a & 3.4 & 6.9 & 0.1 \\
\hline$F-2 a$ & 1.5 & 6.6 & 0.1 \\
\hline \multicolumn{4}{|c|}{${ }^{a}$ Colony forming units } \\
\hline
\end{tabular}

peritoneal injection. The pathogenicity of Vibrio sp. INFL therefore seems to be quite different from that of $V$. anguillarum. Histopathological and electron microscopic examinations revealed that the multiplication of Vibrio sp. INFL and the resultant pathological changes occurred only in the intestine, particularly within the mucosal epithelium. From these results, it can be concluded that 'Chokan-hakudaku-sho' is a local (i.e. non-systemic) infection, with the causative organism exerting its effects in the intestine. The resulting disease should therefore be regarded as a necrotic enteritis.

'Chokan-hakudaku-sho' has been reported to occur in 14 to 30-d-old flounder in hatcheries (Murata 1987. Masumura et al. 1989). This observation was supported by experimental infections using different aged flounder in the present study. The reasons for our failure to produce the disease in 11-d-old fish are not clear. It may be that the amount of bacteria-loaded food (rotifer) taken by this group was smaller than that taken by the older fish groups and that the challenge dose actually administered was insufficient to cause disease. The resistance in 41-and 60-d-old fish could be attributed to the physiological development of the fish. For example, it has been established that differentiation of the stomach begins 20 to $25 \mathrm{~d}$ after hatching and that peptidase secretion commences at $40 \mathrm{~d}$ in the Japanese flounder (Yasunaga 1972).

Enteric diseases of mammals are a complex syndrome involving a variety of infectious agents, secondary opportunists, and precipitating factors (Morris \& Sojka 1985). Certain strains of Escherichia coli are frequently involved in disturbances of the intestinal tract of newborn piglets, calves, and lambs. In enteric colibacillosis, the bacteria are generally confined to the intestinal tract, although the bacteria may become systemic in the terminal stages of disease. Therefore, it can 
be said that 'Chokan-hakudaku-sho' or necrotic enteritis with Vibrio sp. INFL in flounder larvae is similar to enteric colibacillosis of young mammals.

For an Escherichia coli to cause diarrhoea in a susceptible host, it must possess at least 2 virulence determinants. It must be able to colonize the small intestine, which is promoted by colonization antigens or adhesions, and it must be able to produce enterotoxin, which causes the diarrhoea (Morris \& Sojka 1985). Although pili-like structures were not observed on the cells of Vibrio sp. INFL, in vitro adhesive ability was demonstrated on a fish cell line (CHSE-214). The possibility of toxin production by the pathogen has yet to be studied.

It has been demonstrated that Vibrio species are the most dominant isolates among the intestinal flora of healthy larvae of the Japanese flounder, owing to the intake of live diets, highly contaminated with vibrios (Tanasomwang \& Muroga 1988). When these live diets are contaminated with an enteric pathogen like Vibrio sp. INFL, flounder larvae may develop an enteric vibriosis

Responsible Subject Editor: Dr T. Evelyn, Nanaimo, B.C., Canada

\section{LITERATURE CITED}

Fukuhara, O. (1987). Recent trends in mariculture and seed production of fish in southern Japan. In: Sindermann, C. J. (ed.) Reproduction, maturation, and seed production of cultured species. NOAA tech. Rep. U.S. Dep. Commerce NMFS 47: 1-2

Masumura, K., Yasunobu, H., Okada, N., Muroga, K. (1989). Isolation of a Vibrio sp., the causative bacterium of intestinal necrosis of Japanese flounder larvae. Fish Pathol. 24: 135-141

Morris, J. A. Sojka, W. J. (1985). Escherichia coli as a pathogen in animals. In: Sussman, $M$. (ed.) The virulence of Escherichia coli. Academic Press, London, p. $44-77$

Murata, O. (1987). An infectious disease of larval flounder showing opaque intestine. Fish Pathol. 22: 59-61

Osaki, J. (1979). Tests for the difference in percentage. In: Practical statistics for public health research (in Japanese). Kodansha-Scientific, Tokyo, p. 6-17

Tanasomwang, V., Muroga, K. (1988). Intestinal microflora of larval and juvenile stages in Japanese flounder (Paralichthys olivaceus). Fish Pathol. 23: 77-83

Yasunaga, Y. (1972). The development of the digestive gland of the plaice larva, Paralichthys olivaceus. Bull. Tokai reg. Fish. Res. Lab. 69: 75-89

Manuscript first received: September 20, 1989

Revised version accepted: July 4, 1990 